\title{
POSITIVE IMAGE OF WOMEN IN THE EGYPTIAN ADVERTISEMENT
}

\author{
Sarah Mohamed Abdel Nasser JABER *
}

Department of Graphic and Advertising Arts, Higher Institute of Applied Arts, $6^{\text {th }}$ of October City, Egypt

\begin{abstract}
The research discusses the concept of identity, its types, the societal identity, the concept of values women and their types, the classification of values and the concept of ethics, theories of human values to measure the ethics of advertising, the positive change in the recipient's attitudes, the Egyptian declaration and values, and it also discusses. Egyptian advertising: The personality of women in advertising design, character design, then the characteristics of designing the woman's personality in advertising, the use of women as an element of attraction in advertising, and how to build a positive mental image of women in advertising design, then discuss the exploitation of women in advertising, and the positive effects of good employment of women in Ads, and design elements And its determinants, then the social and moral responsibility of advertising, and how to deal with the problem of negatively exploiting the image of women, the controls that regulate advertising practices, then the descriptive and analytical part of the research, the results of the research and its recommendations, and finally the research references.

Keywords

Positive, Image, Women, Egyptian, Advertisement.
\end{abstract}

\section{Introduction}

Many advertisers exploit women in a way that is their motivation Many ancient and contemporary artists were mainly influenced by the aim of which is to arouse deceit and attract attention Women for the sake of creativity, she was drawing, sometimes in a complicated way, and sometimes for advertising without taking into account the main goal of . Another simple and always-liked image of the woman is the advertisement, which is the recipient's purchase of the product or service. And surprise, appreciation and interpretation, it has become an area for controversy and creativity in some cases, the use of women as an image and the subject of women in contemporary culture has become a beautiful thorny element that attracts attention without looking at the relationship of the image to the product. And it has much interference that is subject to discussion in the forums or the service provided This makes the image of women in cultural, women's, social and Arab levels a commodity to be bought and sold and not an important part of the recipients and global in light of the changes that plague the world since the beginning of the potential for the advertised good or service.

\section{Research Problem:}

goals and values that affect the direction of the individual, which in turn affects whether the image of women can be exploited in a positive way in his behavior and on the culture of society. Negativity, which appeared most often in the form of the sexy girl.

The research aims to emphasize that the use of the image Promotion and advertising of

\footnotetext{
* Corresponding author: info@appliedarts.edu.eg
} 
commodities in positive publications for women in advertising achieves the objectives of the advertisement Posters and also in mobile and static visual desired.

\section{Research Methodology:}

There is no doubt that the research follows the descriptive analytical approach.

The exploitation of the woman's body in these cheap ways contributes to destroying the structure and form of Arab society by arousing instincts and publish moral decay.

Cultural identity: it is the identity that links to the concept of culture the distinguished woman and its uprooting from its Islamic roots and originality in which a society is distinguished, and directly dependent on her principles and marginalization of her role, so the means of language must be careful, as the cultural identity is distinguished by its transfer of the nature of the language. Society, its behaviors and its culture as one of the main factors in building the culture of individuals in its prevailing beliefs and not excessive imitation and borrowing from society. Others without distinguishing between what is appropriate and what is not suitable for society. Age identity: It is the identity that contributes to classifying the Arab, and this research offers some suggestions and pictures of individuals according to their age stage, and it is divided into childhood that enhances its positive role in the development of society. And youth, manhood and old age.

\section{1- Given identity:}

it is the characteristics and characteristics that he is able to integrate and coexist with his group and feel that he is one of the circumstances in which the individual has no role in choosing the members of this group. Gender, birth order, and moral characteristics, as well as a set of characteristics that individuals possess, and religion that contribute to making them achieve the characteristic of uniqueness from others.

\section{2- Selected identity:}

It is a set of characteristics in which these characteristics are common to a group of people, whether the individual voluntarily chooses such as profession and hobby within the community or state, which is the common thing between individuals and the political trend. A specific group, or social segment.

\section{3- Core identity:}

It is the characteristics that make the general state of a country and the division of identity into a group of individual types, such as personal characteristics that distinguish him, and each type contributes to referring to a term or idea, behavior, beliefs, values and skills Moral values help in images in the social sphere. Classification of values: Values have many types, including theoretical, political, economic, aesthetic, social and religious value. Theoretical values: They 
are philosophical ideas and principles of knowledge so that the individual understands the laws around him that govern these things with the intention of knowing them and in the habit of philosophers and thinkers are the ones who They search in it as an individual searches about the nature of the earth, the planets, the sun, night and day, so his belief in these values is considered theoretical.

\section{References}

1- Ahmed Zayed - The Psychology of Relations between Groups - Society in Achieving the Highest Degree of Human Needs, Alam Al-Ma'rifah Magazine, Issue - Kuwait - Focusing on new advertising methods that change the recipient's attitudes and transmit human values and associated customs.

2- Amira Helmy Matar - An introduction to aesthetics and a philosophy of civilizational identity in our Arab and Egyptian societies. Art - Dar Al Maaref - First Edition - 17.

Women are an important human resource that can be used

3- Iman Salah Hanafi - Societal identity and its relationship and benefiting from it in advertisements and product promotion with the design determinants of advertising campaigns to address, but taking into account the importance of preserving women's issues - Journal of Architecture and Arts, Eastern Arab Identity for Women and Humanities - Issue 10 - 2017.

4- Advertising agencies should take advantage of the positives of the times - Ragheb Al Rikabi - Liberal Ethics - 2009. Modernity and openness in line with our Arab traditions ... Shaybah The announcement "The Introduction and Theory"- Sharqia and the Egyptian women appearing in advertisements, House of Knowledge University - Alexandria - 2009. Modestly and in a manner appropriate to Arab reality without

5- Safwat Al-Alam - The advertising communication process - Fourth Edition sexual or verbal connotations - Alam Al-Kutub - Cairo - 2009. Research recommendations:

6- Tariq Mandour - Fawzi Fahmy - Journalism and its Freedom 1 - The necessity of setting cultural and social variables Arts and their unity - writings that have not been published, the centenary of the Doctor of Community Individuals into account when doing the work of Muhammad Mandour - The Family Library - 2009. Design treatments for women's issues

7- Izzat Muhammad Saad - Product Design Philosophy - 9- Addressing women's issues in a manner that does not violate the ethics of the publishing society. Author - 12. It does not reduce the value of women in it

8- Essam El Din Ahmed Farag - Pictures of women in advertisements 3- The necessity of adopting advertisements directed to address the issues of Egyptian television - Analytical study of women's advertisements on innovation and renewal in proportion to Egyptian television in 
19- Ph.D.- Faculty of Developments in Cultural and Societal Change and its Reflection on Media - Cairo University 18 - Culture of community members.

9- Fatima Shaaban Saleh - The role of television advertising in 4- The advertising campaigns must be subject to censorship to direct adolescents' behavior - An applied study on the quality of the advertising message presented to the community to the danger of Egyptian adolescents - Master - Studies Department of its impact, negatively or positively, on media public opinion - Research Institute Arab Studies - for society. The Arab Organization for Education, Culture and Science - Cairo - 5. Conducting a deep study on the reality of Arab societies. Creation of advertising personalities models compatible with the nature

10- Fawzia Diab - Social values and customs - the authority of those societies without the application of ready-made models that succeeded in the Egyptian Book - 2009 in the West on the conservative eastern societies under

11- Fouad Ismail - Advertising Environment and Strategy - College of Globalization Logos. Commerce - Al-Azhar University - Cairo - 2012 6. The realistic role that women play in 12- Fouad Al-Bahi Al-Sayed - Social Psychology - The science of society in the design of the advertisement. The woman who decides social psychology - Dar Al-Fikr Al-Arabi - Cairo and his professions and not only a wife and a slave. 2- The designer of the advertisement must pay attention to studying the needs of

13- Kelly Hum Hunom - translated by Khaled Abdul Rahman Awad - Society to design advertising messages based on generating values of community identity (self-knowledge and leadership of others) - a new humanity working to make a positive impact in Obeikan Publishing - Riyadh 2009. Attitudes of the recipient towards the advertised product or service. 14- Muhammad Fahmi Omran - Building the Brand 9- Advertising institutions must consolidate values and design their identity - First Edition - the human kingdom in advertising according to the societal condition that the Hashemite Jordanian society lives in.

16- Mona Saeed Al-Hadidi - Salwa Imam Ali - Announcement $\vee$-- The design culture is developed by strengthening its foundations, methods and arts. The Egyptian Lebanese House Human Values as a Positive Way to Deliver the Message | Cairo - First Edition - 2009.

15- Hanan Samir ABDEL-AZIM, ELECTRONIC MEDIA DEVELOPMENTS AND THEIR IMPACT ON CHANGING THE POSITIVE VALUES OF SOCIETY, International Journal of Humanities and Language Research, Vol. 1, No. 2, 2018, pp. 1-6. 